\title{
Peripheral embolization following thrombolytic therapy for acute ischemic stroke-a case report
}

\author{
Tamer Roushdy ${ }^{1}$, Eman Hamid ${ }^{1}$, Mai Fathy ${ }^{1 *}$ (D) Islam Bastawy², Hany Aref $^{1}$ and Nevine El Nahas
}

\begin{abstract}
Background: Intravenous recombinant tissue plasminogen activator is the only golden approved medical therapy for acute ischemic stroke, guidelines for its injection relay on reducing or preventing associated hemorrhage as a side effect, yet hemorrhage is not the only possible complication, further embolization following injection is also a possibility; in this case report, peripheral embolization following intravenous recombinant tissue plasminogen activator with two possible explanations one related to the treatment and another related to the patient liability is represented.
\end{abstract}

Case presentation: A 78-year-old male presenting with acute onset of stroke, received intravenous recombinant tissue plasminogen activator, $16 \mathrm{~h}$ later he developed acute limb ischemia.

Conclusion: Peripheral embolization may happen within hours from intravenous recombinant tissue plasminogen activator administration.

Keywords: Thrombolytic therapy, Acute stroke, Peripheral embolization, Intra-cardiac thrombus

\section{Background}

Caring for stroke patients after intravenous recombinant tissue plasminogen activator (IV rt-PA) is important as an injection decision. Caring goes beyond vital data, to involve detecting and avoiding any possible complications from rt-PA [1].

Other devastating complications rather than the wellknown hemorrhage may occur. Peripheral embolization is a one. In this case, peripheral embolization after rt-PA with two possible explanations is represented.

\section{Case presentation}

A 78-year-old male, hypertensive, ischemic heart disease patient with previous transthoracic echocardiography in 2015 showing dilated left atrium and left ventricle (LV), with impaired LV systolic functions (ejection fraction (EF) measured by modified Simpsons' method was 40\%), LV diastolic dysfunction impaired relaxation pattern, normal

\footnotetext{
* Correspondence: maifathy23@gmail.com

${ }^{1}$ Neurology Department, Faculty of Medicine, Ain Shams University, Cairo, Egypt

Full list of author information is available at the end of the article
}

right-side chambers, and aortic root, no intra-cardiac masses or thrombi, with resting segmental wall motion abnormalities in left anterior descending artery territory.

In July 2016, he developed ischemic stroke with NIHSS 7 (minor facial paresis, grade 3 left arm, and leg weakness).

Radial pulse was 60 beats/min, bilaterally equal, regular, and well felt. Electrocardiography (ECG) (CM 300A, Comen, China) showed sinus rhythm. After fulfilling the inclusion and exclusion criteria for thrombolysis, $90 \mathrm{mg}$ IV rt-PA within $40 \mathrm{~min}$ of arrival was administered. After injection, NIHSS became 4 . Meanwhile, patient did not complain of any symptoms suggestive of peripheral vascular events.

Sixteen hours later, loss of partially regained power of the left arm with bluish discoloration, and faint radial pulsation occurred.

Urgent upper limb arterial duplex (General Electric Logic 5, USA) revealed unrecoverable ischemia with near-total occlusion of the left mid-brachial artery with total loss of flow in distal arteries, the vascular surgery team decided an above elbow amputation (Fig. 1a).

Springer Open

(c) The Author(s). 2020 Open Access This article is licensed under a Creative Commons Attribution 4.0 International License, which permits use, sharing, adaptation, distribution and reproduction in any medium or format, as long as you give appropriate credit to the original author(s) and the source, provide a link to the Creative Commons licence, and indicate if changes were made. The images or other third party material in this article are included in the article's Creative Commons licence, unless indicated otherwise in a credit line to the material. If material is not included in the article's Creative Commons licence and your intended use is not permitted by statutory regulation or exceeds the permitted use, you will need to obtain permission directly from the copyright holder. To view a copy of this licence, visit http://creativecommons.org/licenses/by/4.0/. 

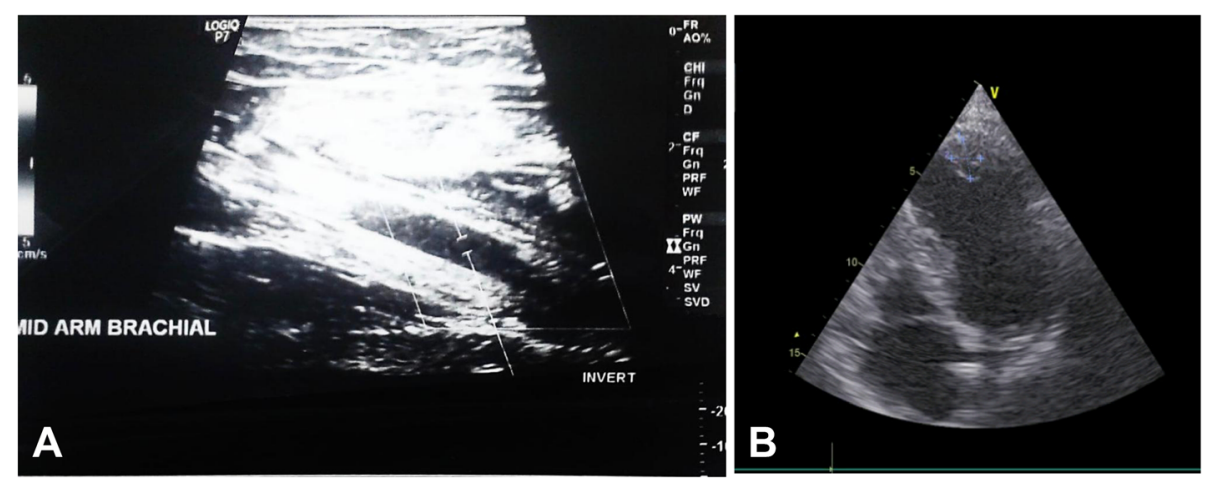

Fig. 1 (a) Duplex revealing absence of blood flow along mid-brachial artery (b) transthoracic ECHO revealing LV thrombus

Transthoracic echocardiography (Vivid E9 machine, General Electric, Vingmed Ultrasound, Horten, Norway) done after surgery revealed $19 \times 14 \mathrm{~mm}$ apical LV thrombus, dilated LV dimensions, with impaired LV systolic functions (ejection EF measured by modified Simpsons' method was 35\%), akinetic all apical segment, whole anterior wall and anterior septum, impaired LV diastolic function with impaired relaxation pattern with mild mitral and tricuspid valve regurgitation (Fig. 1b). Twenty-four hours Holter ECG (General Electric Health care, MARS, Milwaukee, USA) showed sinus rhythm with no detectable atrial fibrillation.

\section{Discussion}

Thrombus develops from transient activation of coagulation systems based on the pharmacokinetics of fibrin specific thrombolytics through converting plasminogen into plasmin on clot-bound fibrin $[1,2]$. This reduces circulating fibrin by $16-36 \%$ and fibrinogen by $16-62 \%$ [3]. rt-PA half-life of $26-40$ min allows fibrinogen, plasminogen, and alpha- 2 anti-plasmin concentrations to return to nearly their pre-injection levels within 2-24h [4-6].

LV thrombus formation is common with impaired EF, anterior wall with apical dyskinesia. Embolization is common with bigger thrombi with protruding freely mobile pedicle, and with borders adjacent to hyperkinetic segments [7-9]. Thrombus fibrin nature whether thick or thin also affects rt-PA lysis ability [10].

In our case, peripheral ischemia was secondary to embolization from LV thrombus that either presented earlier to rt-PA and thrombolysis fragmented it or developed following rt-PA on top of the patient's cardiac state.

What has made our case challenging and may have delayed early detection of limb ischemia was that peripheral embolization took place along the ipsilateral paretic limb that although initially showed improvement post rt-PA, yet not to the extent that will make the patient oriented to a new symptom whether paresthesia or paralysis.

Also, the patient had a dark skin color that reduced the ability to detect color changes that usually accompany peripheral ischemia [11].

\section{Conclusion}

Peripheral embolization can occur within hours following rt-PA administration, either secondary to its pharmacokinetics alone or due to incomplete lysis of an intra-cardiac mural thrombus, so it is worth mentioning that patients with a high risk of or history suggestive of intra-cardiac thrombus might benefit from hand-in-hand bedside echocardiography while administering rt-PA searching for intra-cardiac LV thrombus that if found will make closer monitoring for signs or symptoms of peripheral embolization mandatory to the degree of merging it into current post-injection care of patients.

\section{Acknowledgements}

Not applicable

\section{Authors' contributions}

TR: Conception of the work and drafting of the manuscript. EH: Acquisition and analysis of data. MF: Acquisition and analysis of data. IB: Cardio logical assessment and performing echocardiography. HA: Contributor in writing the manuscript. NE: Contributor in writing the manuscript. All authors have agreed to conditions noted on the Authorship Agreement Form and have read and approved the final version submitted.

\section{Funding}

No funds were received to fulfill this work.

\section{Availability of data and materials}

The corresponding author takes full responsibility for the data, has full access to all of the data, and has the right to publish any and all data separate and apart from any sponsor.

\section{Ethics approval and consent to participate}

The study was approved by Ain Shams University Ethical Committee (date of approval: April 6, 2017) (reference number not available).

\section{Consent for publication}

Written informed consent was obtained from the patient for publication of this case report, the revealing data and accompanying images and is available upon request. 


\section{Competing interests}

None of the authors has any conflict of interest.

\section{Author details}

${ }^{1}$ Neurology Department, Faculty of Medicine, Ain Shams University, Cairo, Egypt. ${ }^{2}$ Cardiology Department, Faculty of Medicine, Ain Shams University, Cairo, Egypt.

Received: 10 August 2020 Accepted: 23 September 2020

Published online: 08 October 2020

\section{References}

1. Gill R, Donahey E, Ruland S. Early administration of therapeutic anticoagulation following intravenous thrombolysis for acute cardiogenic embolic stroke caused by left ventricular thrombus: case report and topic review. Front Neurol. 2015;6:9.

2. Acheampong P, Ford GA. Pharmacokinetics of alteplase in the treatment of ischaemic stroke. Expert Opin Drug Metab Toxicol. 2011;8(2):271-81.

3. Mueller $\mathrm{H}$, Rao A, Forman S. Thrombolysis in myocardial infarction (TIMI): comparative studies of coronary reperfusion and systemic fibrinogen lysis with two forms of recombinant tissue-type plasminogen activator. J Am Coll Cardiol. 1987:10(3):479-90.

4. Nilsson T, Wallén P, Mellbring G. In vivo metabolism of human tissue-type plasminogen activator. Scand J Haematol. 1984;33(1):49-53.

5. Tanswell P, Seifried E, Su PC, Feuerer W, Rijken DC. Pharmacokinetics and systemic effects of tissue-type plasminogen activator in normal subjects. Clin Pharmacol Ther. 1989;46(2):155-62.

6. Tanswell P, Tebbe U, Neuhaus K, Gläsle-Schwarz L, Wojci K, Seifried E. Pharmacokinetics and fibrin specificity of alteplase during accelerated infusions in acute myocardial infarction. J Am Coll Cardiol. 1992;19(5):10715

7. Chiarella F, Santoro E, Domenicucci S, Maggioni A, Vecchio C. Predischarge two-dimensional echocardiographic evaluation of left ventricular thrombosis after acute myocardial infarction in the GISSI-3 study. Am J Cardiol. 1998;81(7):822-7.

8. Delewi R, Zijlstra F, Piek J. Left ventricular thrombus formation after acute myocardial infarction. Heart. 2012;98:1743-9.

9. Haugland JM, Asinger RW, Mikell FL, Elsperger J, Hodges M. Embolic potential of left ventricular thrombi detected by two-dimensional echocardiography. Circulation. 1984;70(4):588-98.

10. Carr ME Jr, Alving BM. Effect of fibrin structure on plasmin-mediated dissolution of plasma clots. Blood Coagul Fibrinolysis. 1995;6(6):567-73.

11. Polfer E, Zimmerman R, Tefera E, Katz R, Higgins J, Means K. The effect of skin pigmentation on determination of limb ischemia. J Hand Surg. 2018; 43(1):24-32.

\section{Publisher's Note}

Springer Nature remains neutral with regard to jurisdictional claims in published maps and institutional affiliations.

\section{Submit your manuscript to a SpringerOpen ${ }^{\circ}$ journal and benefit from:}

- Convenient online submission

- Rigorous peer review

- Open access: articles freely available online

- High visibility within the field

- Retaining the copyright to your article

Submit your next manuscript at $\boldsymbol{\nabla}$ springeropen.com 